\title{
Granice odpowiedzialności dyscyplinarnej
}

Problem, czym jest odpowiedzialność dyscyplinarna, zdaje się być dzisiaj nie tylko zagadnieniem nurtującym teoretyków, ale posiadać także doniosłe znaczenie praktyczne. Łatwo bowiem można zaobserwować wżrost jej znaczenia w życiu publicznym oraz wzrost oczekiwań społecznych, aby za jej pomocą szybko i zdecydowanie reagować na występujące patologie. Potrzeba badań w tym zakresie staje się tym bardziej pilna, iż brak, jak dotychczas, zgody wśród przedstawicieli nauki co do charakteru prawnego odpowiedzialności dyscyplinarnej, a w konsekwencji co do jej przesłanek oraz organów i procedury, w ramach których mogłaby być ona skutecznie i w sposób odpowiadający jej funkcjom egzekwowana.

Nie sądzę jednak, aby była możliwa do skonstruowania i potrzebna wyczerpująca definicja odpowiedzialności dyscyplinarnej, która w sposób jednolity obejmowałaby wszystkie instytucje prawne mniej lub bardziej tradycyjnie tym terminem określane. Przedsięwzięcie takie bowiem musiałoby mieć charakter projektowania pojęć, które łatwo może skończyć się nieadekwatnością a co najmniej nieintuicyjnościa jego wyniku. $Z$ metodologicznego punktu widzenia bardziej poprawne i owocne wydaje mi się analizowanie tradycyjnych instytucji, które określa się jako odpowiedzialność dyscyplinarna, ze szczególnym uwzględnieniem używanego w tym zakresie języka prawnego i prawniczego. Należy w tym miejscu zaznaczyć, że ze względu na częstą lakoniczność przepisów dotyczących odpowiedzialności dyscyplinarnej, to właśnie praktyce przypada rola eksplikowania reguł, na których jest oparta ta instytucja. 
Proponowana analiza nie jest celem samym w sobie. Wskazanie cech charakterystycznych instytucji prawnej powinno służyć jej doskonaleniu, nawet jeśli nie wprost formułując konkretne postulaty, to przynajmniej dając teoretyczne podstawy do dyskusji nad kryteriami poprawności jej funkcjonowania. W przypadku odpowiedzialności dyscyplinarnej główną kwestią w tym zakresie zdaje się być groźba arbitralności i nadużyć przy jej wymierzaniu, w które może stosunkowo łatwo przerodzić się właściwe jej swobodne uznanie. Teoria odpowiedzialności dyscyplinarnej powinna wskazywać granice tego uznania, bez nich bowiem instytucja ta będzie skazana na rozpad. „Swobodne uznanie jest jak otwór w pączku angielskim, nie istnieje inaczej niż jako wolny obszar otoczony pasmem ograniczeń"'.

Jako źródła odpowiedzialności dyscyplinarnej można wskazać dwie tradycje. Współcześnie odpowiada im to, co nazywa się odpowiedzialnością dyscyplinarną sensu largo i sensu proprio ${ }^{2}$. Pierwsza $z$ nich jest zwiazana ze stosunkami pracowniczego podporządkowania i wymierzana przez pracodawce, przede wszystkim za naruszenia przepisów porządkowych obowiązujących pracownika co do zasady ze względu na zawartą między nimi umowę o pracę. Jako taka jest więc instytucją prawa pracy, a więc w gruncie rzeczy prywatnoprawna. Historycznie wynika ona ze zwykłej odpowiedzialności kontraktowej, która z czasem uległa częściowemu wyłączeniu z zakresu obowiązywania zasady swobody umów i ze względu na potrzebę szczególnej ochrony pracowników poddana regulacji przepisami niedyspozytywnymi.

Z kolei to, co nazywa się odpowiedzialnością dyscyplinarna, we właściwym czy ścisłym rozumieniu tego słowa, oznacza odpowiedzialność realizowaną przez organy powołane do kontrolowania lub nadzorowania wykonywania określonych zawodów lub sprawowania określonych funkcji. Ich cechą wspólnąjest zaufanie publiczne, którym $z$ jednej strony osoby i całe ich grupy cieszą się w społeczeństwie, a które, $z$ drugiej strony, jest niezbędne do prawidłowego wykonywania owych zawodów lub funkcji. Podstawą tego typu odpowiedzialności dyscyplinarnej są przepisy prawa publicznego dotyczące

${ }^{1}$ R. Dworkin, Biorqc prawa poważie, Warszawa 1998, s. 73.

${ }^{2}$ A. Wasilewski, Prawo do sqdu w sprawach dyscyplinarnych (ustawodawstwo polskie na tle standardów Europejskiej Konwencji o Ochronie Praw Czlowieka i Podstawowych Wolności oraz Konstytucji RP), „Przegląd Sądowy” 2001, nr 9, s. 16. 
danych służb czy wolnych zawodów. Historycznie zdaje się ona wywodzić $z$ sądownictwa honorowego czy zawodowego zawodów medycznych i prawniczych, które kształtowało się przez wieki ${ }^{3}$.

Należy zaznaczyć, że niektóre $z$ omawianych zawodów i funkcji podlegających odpowiedzialności dyscyplinarnej w drugim sensie także mogą być wykonywane na podstawie umów o pracę, ale właśnie ta szczególna, publicznoprawna regulacja ich odpowiedzialności dyscyplinarnej jest racją ich wyodrębnienia. Nie tylko bowiem podlegajajej zawody i funkcje, w których nie ma dla niej podstaw z zakresu prawa pracy, ale także takie, w których teoretycznie możliwość ta istniałaby, jednak $z$ pewnych względów zdecydowano się ją wyłączyć.

Także odpowiedzialność dyscyplinarna wymierzana w ramach zakładów administracyjnych może nasuwać pewne problemy związane $z$ omawianym rozróżnieniem, zaburzając klarowność tej dychotomii. $Z$ jedenej strony wskazuje się, że: „Za naruszenie poleceń organów zakładu użytkownik może być ukarany karami dyscyplinarnymi, z których najostrzejszą jest usunięcie $z$ zakładu"4, $z$ drugiej jednak należy pamiętać, że użytkownicy zakładu często posiadają własny samorząd, który ma możliwość mniej lub bardziej bezpośredniego wpływania na organy dyscyplinarne. Również analiza materialnoprawnych przesłanek odpowiedzialności dyscyplinarnej w takich zakładach nie prowadzi bezpośrednio do wniosku, iż odpowiedzialność tę można wymierzać za samo naruszenie poleceń wydawanych na podstawie władztwa zakładowego. Tak na przykład jest w przypadku studentów szkół wyższych, których przedstawiciele zasiadają w komisjach dyscyplinarnych, samorząd studencki ma możliwość powołania sądu koleżeńskiego, przynajmniej częściowo alternatywnego wobec organów dyscyplinarnych, a podstawą odpowiedzialności jest naruszenie przepisów obowiązujących w uczelni i/lub uchybienie godności studenta. Wydaje się więc, iż podział na odpowiedzialność sensu largo oraz sensu proprio ma raczej charakter rekonstrukcji pewnych modeli, które siłą rzeczy upraszczają skomplikowany i różnorodny obraz powolanych do życia przez prawodawcę

${ }^{3}$ Por.: G. Holly, Geschichte der Ehrengerichtsbarkeit der deutschen Rechtsanwälte, Frankfurt am Main-Bern-New York-Paris 1989, który obszernie omawia także rozwój instytucji odpowiedzialności dyscyplinarnej we Francji, mającej duży wpływ na jej rozwój w państwach niemieckich.

${ }^{4}$ M. Wierzbowski [red.], Prawo administracyjne, Warszawa 2007, s. 114. 
instytucji odpowiedzialności dyscyplinarnej, co jednak w żadnym stopniu nie umniejsza ich wartości poznawczej. Dzięki nim bowiem ten skomplikowany i różnorodny obraz można opisać i zrozumieć, a w konsekwencji także poddać krytyce.

Ta różnorodność źródeł odpowiedzialności dyscyplinarnej wskazuje i jednocześnie thumaczy wiele różnic między nimi zarówno w zakresie prawnej regulacji, jak i przypisywanych funkcji, a więc także wykładni dotyczacych ich przepisów. Zwracają uwagę przede wszystkim dwie okoliczności. Po pierwsze, w obu typach inny jest stosunek między osobą podlegającą a osobami wymierzającymi odpowiedzialność, przy czym chodzi tu o stosunek w rozumieniu czysto społecznym, a nie prawnym. Stosunki prawne w tym przypadku celowo są ukształtowane inaczej niż faktyczne relacje między ich stronami. I tak w przypadku odpowiedzialności dyscyplinarnej sensu largo między pracownikiem a pracodawcą występuje stosunek nadrzędności strony silniejszej nad słabsza, który właśnie prawo pracy, a w szczególności prawo dyscyplinarne, ma zmniejszać czy łagodzić. W przypadku natomiast odpowiedzialności sensu proprio, w szczególności tej wymierzanej w ramach samorządów zawodowych, osoby orzekające są zazwyczaj przedstawicielami tego samego zawodu i co do zasady posiadają równy status. Jest to więc swoisty „sąd równych", tradycyjnie szumnie nazywany ,sądem braci” itp. Przepisy prawne służą tu zniwelowaniu tej równości i poddaniu osób wykonujących dany zawód władzy organów dyscyplinarnych.

Po drugie, pracownicza odpowiedzialność dyscyplinarna jest nakierowana głównie na egzekwowanie mniej lub bardziej sprecyzowanych obowiązków wynikających ze stosunku pracy. Innymi słowy, jej podstawą jest nierealizowanie konkretnych świadczeń, do których pracownik sam się zobowiązał, mogące w ostateczności prowadzić do rozwiązania stosunku pracy. W przypadku drugiego typu odpowiedzialności dyscyplinarnej chodzi natomiast nie tyle o wypełnianie obowiązków, ile o ochronę pewnych dóbr, ponieważ „Łączy się ona przede wszystkim ze specyfiką wykonywania niektórych zawodów oraz zasadami funkcjonowania konkretnych korporacji zawodowych. Uksztaltowane w ich ramach reguly deontologiczne ukierunkowane są przede wszystkim na obronę honoru i dobra zawodu [...]. Takie zasady odpowiedzialności przewiduje się zwłaszcza w odniesieniu do zawodów o dużym prestiżu społecznym (nauczyciele, lekarze, prawnicy), gdzie należyta troska o ich godność jest ważnym jego elementem [...] Shużyć ma [...] przeciwdzialaniu takim zachowaniom, które mogłyby pozbawić ją [grupe 
zawodową-przyp. P.S.] wiarygodności w oczach opinii publicznej, co ma szczególne znaczenie, gdy chodzi o autorytet instytucji użyteczności publicznej"s.

Powyższe ustalenia dają podstawę do rozważań nad funkcjami odpowiedzialności dyscyplinarnej. Wydaje się, że omówiony powyżej dualizm typów odpowiedzialności dyscyplinarnej można przełożyć na owe funkcje, wyróżniając $z$ nich dwie podstawowe, zaznaczając jednak od razu, że przyporządkowanie między nimi nie ma jednoznacznego charakteru i będzie wymagać komentarza. W literaturze i orzecznictwie dominuje traktowanie odpowiedzialności dyscyplinarnej sensu proprio jako rodzaju odpowiedzialności represyjnej, a więc główną jej funkcją byłoby ukaranie osoby obwinionej (funkcja represyjna). Chce w tym miejscu przeciwstawić się temu tradycyjnemu poglądowi, bronić natomiast stanowiska, że przed nadużyciem swobodnego uznania w zakresie tego typu odpowiedzialności dyscyplinarnej efektywnie może zabezpieczyć tylko postawienie jej zadania zapewnienia, wśród osób wykonujących dany zawód lub sprawujących funkcje, osobistych postaw i społecznego zaufania w tym celu niezbędnych (funkcja integracyjna).

Pogląd tradycyjny jest przede wszystkim konsekwencją ujmowania prawa dyscyplinamego jako czesści prawa karnego. Jak pisze Marian Cieślak: „prawo dyscyplinarne [...] wprost uważać można za szczególną gałąź czy rodzajową odmianę prawa karnego"6. Pogląd ten był przywoływany przez Trybunał Konstytucyjny oraz przezeń aprobowany i wykorzystywany jako przesłanka rozumowań w uzasadnieniach orzeczeń dotyczących odpowiedzialności dyscyplinamej ${ }^{7}$. Trybunał nie przywołuje jednak dałszej części wywodu, w której autor stwierdza, że „Od państwowego prawa karnego różni się ono swym partykularnym, nie powszechnym charakterem, i zaliczane bywa do szeroko rozumianej dziedziny prawa administracyjnego"s, a więc sam zaznacza, że rzecz wcale nie jest tak oczywista. Dyskusyjność tezy, iż

s Wyrok TK z 27 lutego 2001 r., K 22/00 (OTK ZU 2001/3/48).

${ }^{6}$ M. Cieślak, Polskie prawo karne. Zarys systemowego ujęcia, Warszawa 1994, s. 22-23. Inne opracowania z zakresu prawa karnego zazwyczaj w ogóle nie poruszają tego zagadnienia.

7 Wyroki TK z 8 grudnia 1998 r., K 41/97 (OTK ZU 1998/7/117) oraz z 16 listopada 1999 r., SK 11/99 (OTK ZU 1999/7/158).

${ }^{8}$ M. Cieślak, Polskie prawo..., s. 23. 
prawo dyscyplinarne jest prawem represyjnym zdaje się potwierdzać to, co powiedziano tu wcześniej o związkach odpowiedzialności dyscyplinarnej sensu largo z prawem prywatnym i sensu proprio z prawem publicznym.

Nie sądzę, aby na podstawie twierdzeń o rodzajowej przynależności prawa dyscyplinarnego do konkretnej gałęzi prawa można było dojść do konstruktywnych wniosków w zakresie jego funkcji. Stosunek jest tu raczej odwrotny, tj. na podstawie funkcji, jakie ma spełniać lub spełnia odpowiedzialność dyscyplinarna można wskazać jaką metodą regulacji powinien poshużyć się lub poshuguje ustawodawca. Takie podejście pozwala uniknąć swego rodzaju dogmatyzmu, który wobec oczywistości zacierania się granic między poszczególnymi gałęziami prawa i nieoczywistości kryteriów ich rozdziału mógłby doprowadzić do wykluczenia, na mocy samych założeń, że prawo dyscyplinarne może być dziedziną kompleksową wymykającą się kategoriom tradycyjnych dogmatyk prawniczych. Innymi słowy, fakt, że mamy do czynienia ze zjawiskiem karania nie przesądza jeszcze jakiemu celowi to karanie ma służyć.

Przy rozpatrywaniu funkcji represyjnej na wstępie należy zaznaczyć, że nie jest najważniejsze jak są $w$ jej zakresie rozłożone szczegółowe akcenty, tj. jakie znaczenie mają elementy sprawiedliwościowe i prewencyjne, oba bowiem są jej immanentne. Szczególnie ten drugi można wskazać jako nieodłączną cechę pracowniczej odpowiedzialności porządkowej, a więc w zasadzie odpowiedzialności dyscyplinarnej sensu largo, ponieważ „odpowiedzialność dyscyplinarna spełnia [...] funkcję przymuszania pracownika do należytego wykonywania swych obowiązków"9. Wyłącznie na tej podstawie można by twierdzić, że przez analogię funkcja ta znajduje zastosowanie także w odpowiedzialności dyscyplinamej sensu proprio, gdzie chodzi o należyte wykonywanie zawodu ${ }^{10}$. Nie uwzględniałoby to jednak okoliczności, że pracownicza odpowiedzialność porządkowa polega na wymierzaniu „kar za naruszenie obowiązku przestrzegania porządku pracy"ll i jako taka stanowi ,w ręku pracodawcy środek realizacji jego uprawnień kierowniczych (dyrektywnych), obok wydawania przez pracodawcę wiążących poleceń pracownikom (których niewykonanie, obok naruszenia

9 P. Przybysz, Prawo do sqdu w sprawach dyscyplinarnych, „Państwo i Prawo" 1998, nr 8, s. 68 .

${ }^{10}$ Ibidem.

"L. Florek, T. Zieliński, Prawo pracy, Warszawa 2006, s. 208. 
innych obowiązków, może pociągać za sobą odpowiedzialność porządkowa)"'l2. Tymczasem w wypadku na przykład wolnych zawodów organy dyscyplinarne nie mają uprawnień kierowniczych wobec podległych im osób, ograniczając się jedynie do kontroli, nadzoru lub pieczy nad wykonywaniem zawodu. Jest to o tyle oczywiste, o ile uznaje się niezależność jako podstawę wykonywania tych zawodów.

Autorzy cytowanych wyżej poglądów dodaja, iż „odpowiedzialność ta spehia w systemie prawa pracy funkcję prewencyjną, represyjną i wychowawczą"13, a więc wyliczają w zasadzie to, co ja nazywam ogólnie funkcją represyjną. Nawet jeśli różnica ta nie jest tylko terminologiczna, to i tak jest $z$ punktu widzenia niniejszych rozważań drugorzędna. Bardziej istotne jest zagadnienie funkcji ochronnej odpowiedzialności dyscyplinarnej, która, moim zdaniem, autorzy niesłusznie pomijają. Jako dość oczywiste założenie przyjmuję że zawsze gdy w gre wchodzi karanie, normy prawne nie tylko chronią dobra, wyznaczając sankcje za zachowania je naruszające, ale jednocześnie chronią adresatów tych norm przed dowolnością i arbitralnością w wymierzaniu kar. W przypadku odpowiedzialności pracowniczej przepisy prawa chronia pracownika przed takim postępowaniem ze strony pracodawcy, wyznaczając dość precyzyjne przesłanki jej wymierzania oparte na pojęciu bezprawności i winy.

Nieco inaczej rzecz wygląda w odniesieniu do odpowiedzialności dyscyplinarnej sensu proprio. Z jednej bowiem strony przesłanki odpowiedzialności są tu bardziej ogólne, przez co w odniesieniu do konkretnych adresatów ochrona zdaje się być słabsza, $z$ drugiej natomiast gwarancje te są przeniesione na zbiorowość czy grupe, w ramach której odpowiedzialność jest wymierzana. Jak wskazuje Trybunał Konstytucyjny, „wyodrębnienie procedur odpowiedzialności dyscyplinarnej [...] znajdować może podstawę w specyfice poszczególnych grup zawodowych oraz ochronie ich autonomii i samorządności"14, a odpowiedzialność dyscyplinarna „tworzy funkcję ochronną i w ten sposób zapewnia członkom danej korporacji niezbędną swobodę i niezależność przy wykonywaniu zawodu"'s. Dlatego też na przykład „określone jednostkowe zachowanie sędziego uchybiające godności

\footnotetext{
12 Ibidem, s. 208-209.

13 Ibidem, s. 209.

${ }^{14}$ Wyrok TK z 8 grudnia 1998 r., K 41/97 (OTK ZU 1998/7/117).

15 Ibidem.
} 
zawodu sędziowskiego i podważające zaufanie niezbędne do wykonywania zawodu może prowadzić do wydalenia sędziego $z$ zawodu $j$ e d y $n$ i e [podkr. - P.S.] w drodze postępowania dyscyplinarnego"16. Oznacza to, że ze względu na funkcję ochronną istnieją czyny, za które można ponosić wyłącznie odpowiedzialność dyscyplinarna, a podstawowym tego uzasadnieniem jest ponownie niezależność pewnych zawodów.

Sądzę, że w odniesieniu do odpowiedzialności dyscyplinarnej sesnu proprio, z przedstawionego powyżej zawężenia zakresu funkcji represyjnej i rozszerzenia zakresu funkcji ochronnej dość jasno wynika potrzeba poszukiwania osobnej funkcji, którą miałaby ona spełniać i na podstawie której można by sformułować postulaty dotyczące granic swobodnego uznania w jej wymierzaniu. Jeśli bowiem nie ma ona służyć przede wszystkim wymierzaniu sankcji za niewypełnianie konkretnych obowiązków, a jednocześnie immunizuje całe grupy zawodowe przed odpowiedzialnością o charakterze powszechnym (oczywiście w pewnym tylko zakresie), to łatwo może dojść do uczynienia z niej instytucji fasadowej, która umożliwia bezkarne i niekontrolowane postępowanie członków podlegających jej grup zawodowych czy społecznych. Poszukiwana funkcja ma więc dwa aspekty: po pierwsze, wykluczenie nadużycia odpowiedzialności dyscyplinarnej wobec osób jej podlegających, a więc możliwego ze względu na swobodne uznanie, a po drugie, wykluczenie jej nadużycia wobec państwa i społeczeństwa, a więc możliwego ze względu na chronioną przez nią niezależność.

Oba te aspekty można odnaleźć w funkcji, którą nazywam integracyjną. Od strony formalnej polega ona na zapewnieniu spójności praktyki w zakresie wykonywania danego zawodu lub sprawowanej funkcji, przy czym spójność ta może być wielorako rozumiana ${ }^{17}$. W pierwszym rozumieniu chodzi o integralność moralną, tj. jednolitość czy jedność sądów, czynów i postaw konkretnych osób. W drugim - o integralność zawodową, a więc przede wszystkim o unikanie konfliktu pełnionej roli zawodowej $z$ innymi rolami społecznymi i konfliktu interesów w ramach wykonywania zawodu lub pełnienia funkcji przez konkretną osobę. W trzecim rozumieniu $z$ kolei chodzi o integralność zawodu, czyli jednolitość standardów postępowania całej grupy zawodowej zarówno w odniesieniu do osób spoza tej grupy, jak

${ }^{16}$ Wyrok TK z 9 listopada 1993 r., K Il/93 (OTK ZU 1993/2/37).

${ }^{17}$ P. Skuczyński, Integralność, [w:] H. Izdebski, P. Skuczyński [red.], Etyka zawodów prawniczych. Etyka prawnicza, Warszawa 2006, s. 105-112. 
i w jej ramach. Spójność praktyki zawodowej w tych trzech znaczeniach nie powinna być interpretowana jako swego rodzaju mechaniczne $i$ bezduszne ujednolicanie postaw, skądinąd niedopuszczalne w państwie konstytucyjnym. $O$ wiele bardziej słusznym ujęciem jest potraktowanie jej jako ograniczenie różnorodności i dowolności w wykonywaniu zawodów i sprawowaniu funkcji ze względu na pewne wartości, co w zasadzie jest właściwe każdemu normodawstwu czy działalności regulacyjnej. Jak każda działalność polegająca na ograniczaniu wolności, także wypełniająca funkcję integracyjną odpowiedzialność dyscyplinama podlega ograniczeniom. Sa one zawarte w ustawach dających podstawy normatywne instytucji odpowiedzialności dyscyplinarnej, a w szczególności w przepisach dotyczących materialnoprawnych jej podstaw. Należy zwrócić uwagę, że posługują się one zazwyczaj wprost terminologia moralną, używając takich sformułowań, jak „godnosć zawodu”, „etyka zawodowa” itp. Tak więc odpowiedzialność dyscyplinarna ma zapewniać integralność moralną i zawodowa, jak i całego zawodu, w tym jego stosunków ze spokeczeństwem ze względu na wybory aksjologiczne ustawodawcy i tylko w tych granicach.

Rozdzielenie funkcji represyjnej i integracyjnej odpowiedzialności dyscyplinarnej oraz zwiazzanie tej pierwszej $z$ naruszeniem konkretnych obowiazków, tej drugiej natomiast $\mathrm{z}$ kształtowaniem postaw może budzić złe skojarzenia i opór ze względu na postulaty neutralności porządku prawnego i wzajemnej autonomii prawa i moralności. Formowanie ludzkich sumień za pomoca odpowiedzialności prawnej jawiłoby się jako klasyczny przykład moralizmu prawnego, który w każdej swej postaci jest podejrzany. Nie sądzę jednak, aby mogło to podważyć proponowany tu podział. Fakt, że funkcja represyjna dotyczy obowiązków a integracyjna postaw, nie oznacza wcale, że w obu przypadkach nie mamy do czynienia ze zjawiskiem karania i przekreślenia klasycznych wymogów w tym zakresie. Nawet bowiem jeśli uznać, że wyróżnione funkcje odpowiadają karnistycznym koncepcjom opartym na pojęciach , ,czyn" $\mathrm{i}$,społecznie niebezpieczna jednostka" (tu: niedająca reekojmi właściwego wykonywania zawodu), to należy pamiętać, że „konsekwentne uksztaftowanie prawa karnego wedle modelu prawa społecznie niebezpiecznej jednostki nie jest możliwe bez przekreślenia samej istoty prawa karnego"18, a „systemy prawa karnego cechuje

\footnotetext{
${ }^{18}$ M. Cieślak, Polskie prawo..., s. 34.
} 
odpowiedni kompromis między tymi dwoma biegunowymi koncepcjami [...]"' . Ma to zastosowanie mutatis mutandis także do odpowiedzialności dyscyplinarnej, w której punktem wyjścia zawsze powinien być konkretny czyn. Doniosłość rozróżnienia owych funkcji wyraźnie widać, gdy pytamy o to, czy dany czyn stanowi delikt dyscyplinarny i jeśli odpowiedź jest twierdząca, to jaka kara powinna zostać wymierzona. W tym zakresie należy omówić dwa problemy: politycznoprawny, związany z nadużywaniem odpowiedzialności dyscyplinarnej i jej dysfunkcjami jako instytucji, oraz teoretycznoprawny, związany z zakresem i charakterem swobodnego uznania przy wymierzaniu odpowiedzialności dyscyplinarnej.

Pierwszy problem łatwo dostrzec, gdy analizuje się doświadczenie historyczne związane $z$ funkcjonowaniem odpowiedzialności dyscyplinarnej. W stosunkowo łatwy sposób stawała się ona narzędziem walki politycznej i represji wobec przeciwników władzy. Łatwość ta polegała przede wszystkim na tym, że do tej negatywnej instrumentalizacji wystarczyło w zasadzie „odpowiednie podejście" osób zasiadających w organach dyscyplinarnych, nie były natomiast konieczne jakiekolwiek zmiany ustawowe. Dlatego też nie powinien dziwić fakt, że regulacje odpowiedzialności dyscyplinarnej pozostają podobne w różnych porządkach politycznych, niezależnie od stopnia ich demokratyczności.

Moim zdaniem, można wyobrazić sobie trzy koncepcje, które chroniłyby tę instytucję przed nadużywaniem. Po pierwsze, można uznać, że przeciwwagą dla swobody w orzekaniu powinien być staranny dobór osób orzekających, które będą potrafiły korzystać z niej w sposób rozsądny i powściagliwy. Takie podejście zakłada, że nie należy uciekać się do żadnej fikcji w postaci związania organów dyscyplinarnych jakimiś jasnymi regułami, które mogłyby stanowić materialną podstawę odpowiedzialności dyscyplinarnej, ponieważ takich reguł po prostu nie ma. Są one dopiero tworzone w trakcie kształtowania sie linii orzeczniczych, a ich granice wytycza przede wszystkim powściagliwość osób orzekających. Po drugie, można stanąć na stanowisku, że orzecznictwo powinno być w sposób całkowicie formalny związane regułami, które wprost zostały wcześniej sformułowane. Oznaczałoby to odesłanie do ściśle określonych obowiązków zawartych w umowach pracowniczych, regulaminach, instrukcjach czy kodeksach etyki zawodowej przy jednoczesnym zakazie wychodzenia poza nie. Żadna $z$ tych

19 Ibidem. 
koncepcji nie wydaje się poprawna, choć w obu niewątpliwie można odnaleźć prawdziwe tezy. Na pewno należy zgodzić się z konstatacja, że tam, gdzie istnieją ściśle określone obowiązki osób podlegających odpowiedzialności dyscyplinarnej, jej wymierzanie powinno ograniczać się do represji za ich naruszenie. $Z$ taką sytuacją mamy do czynienia w zakresie odpowiedzialności dyscyplinarnej sensu largo. Nie można jednak lekceważyć szerokiego zakresu spraw dyscyplinarnych w obszarze odpowiedzialności dyscyplinarnej sensu proprio, w których takich obowiązków nie ma, ponieważ nawet nie istnieje dokument, w którym mogłyby być zawarte. Ale też nie można zaakceptować podejścia opartego jedynie na powściagliwości organów orzekających jako jedynego zabezpieczenia przed arbitralnością, ponieważ ludzie po prostu bywają różni i nie ma takich mechanizmów, które $z$ jednej strony zagwarantowałyby udział w owych organach jedynie osób posiadających tę cechę, a $\mathrm{z}$ drugiej umożliwiłyby stałą kontrolę ich poczynań wyłącznie na podstawie jasnych kryteriów powściagliwości. Wydaje się, iż „można powiedzieć wręcz, że czysty personalizm jest w ogóle niemożliwy. Ale należy również stwierdzić, że tak samo niemożliwy jest ćzysty instytucjonalizm. Nie tylko bowiem samo powołanie instytucji wymaga ważnych decyzji personalnych, ale i samo ich funkcjonowanie jest w poważnym stopniu zależne od osób, które za nic nie odpowiadają. Instytucje sa jak fortece - muszą być dobrze zaprojektowane i właściwie obsadzone"20. Innymi słowy, etyka zawodowa osób orzekających nie może zastąpić myślenia prawniczego i dyrektyw wskazujących, jak orzekać.

Dlatego shuszniejsza wydaje mi się koncepcja trzecia, która w celu zapewnienia właściwego funkcjonowania instytucji odpowiedzialności dyscyplinarnej, obok wymogów kodyfikowania obowiązów zawodowych czy pracowniczych oraz obsadzania organów dyscyplinarnych osobami rozsqunymi, zakreślałaby granice swobody w orzekaniu i formułowała swoista metodykę orzekania dyscyplinarnego, dzięki której byłoby wiadomo, jak $z$ tej swobody korzystać. Owe dyrektywy orzekania należy traktować jako nieodłączną część instytucji odpowiedzialności dyscyplinarnej, które wspólnie $\mathrm{z}$ relewantnymi normami prawnymi stanowią jej podstawę normatywną. Tylko przy takim założeniu można podejmować próby budowania spójnych procedur intelektualnych, którymi powinny posługiwać się organy dyscyplinarne i w ramach których można uzasadniać konkretne decyzje

${ }^{20}$ K.R. Popper, Spoleczeristwo otwarte i jego wrogowie, Warszawa 2006, t. I, s. 162. 
orzecznicze, wykraczając poza czysty formalizm. Jak sygnalizowałem, źródła tych dyrektyw należy poszukiwać w funkcjach odpowiedzialności dyscyplinarnej, a więc w funkcji represyjnej w przypadku odpowiedzialności sensu largo i funkcji integracyjnej w przypadku odpowiedzialności sensu proprio. Dzięki temu będzie możliwe zarówno interpretowanie przepisów za pomoca metod funkcjonalnych, co przy ich otwartości tekstowej czy wręcz blankietowości wydaje się konieczne, jak i ujęcie samego wymierzania kar dyscyplinarnych jako działalności nakierowanej na określony cel.

Ta politycznoprawna konkluzja generuje jednak doniosłe problemy teoretycznoprawne. Po pierwsze, należy odpowiedzieć na pytanie, czy przy podejmowaniu decyzji orzeczniczych $w$ zakresie odpowiedzialności dyscyplinarnej mamy na każdym etapie do czynienia ze swobodnym uznaniem, a w konsekwencji, czy dyrektywy orzekania formułowane na podstawie jej funkcji mają zawsze zastosowanie. Po drugie, swobodne uznanie można rozmaicie rozumieć, przede wszystkim jako uznanie administracyjne lub dyskrecjonalność sędziowską. W przypadku odpowiedzialności dyscyplinarnej istnieje potrzeba ustalenia, które rozumienie powinno się $\mathrm{w}$ stosunku do niej przyjać, ponieważ determinuje to zakres dyrektyw orzekania. Po trzecie wreszcie, należy wyjaśnić, jak w przypadku odpowiedzialności dyscyplinarnej konkretnej grupy ustalać owe dyrektywy.

W odniesieniu do pierwszego problemu, konieczne jest rozdzielenie dwóch podstawowych momentów podejmowania decyzji orzeczniczej. Pierwszy z nich to ustalenie, czy dany czyn powinien zostać zakwalifikowany jako przewinienie lub delikt dyscyplinarny, natomiast drugi to wymierzenie kary za jego popełnienie. Przy ustalaniu faktu popełnienia przewinienia dyscyplinarnego, a więc udowadniania, że dany czyn rzeczywiście miał miejsce oraz znajdywania reguły objętej odpowiedzialnością dyscyplinarna, którą on narusza, ma zastosowanie wiele zasad procesowych, z zasadą domniemania niewinności na czele. Natomiast „rozstrzygnięcie dotyczące wymiaru kary, czy rodzajowego doboru środków represji nie opiera się już na stopniu prawdopodobieństwa popełnienia czynu, ale wynika $z$ jego charakteru i stopnia stwierdzonej winy. W związku $\mathrm{z}$ tym $\mathrm{w}$ prawie wyraźnie rozdziela się tzw. error in procedendo oraz error in puniendo"21. Pomijając kwestię badania stanu faktycznego, organ dyscyplinarny musi ustalić regułę, która została naruszona oraz prawne konsekwencje tego naruszenia.

${ }^{21}$ Wyrok TK z 27 lutego 2001 r., K 22/00 (OTK ZU 2001/3/48). 
Jak wskazywałem wcześniej, materialne podstawy odpowiedzialności dyscyplinarnej sa zazwyczaj uregulowane bardzo lakonicznie. Przykładowo nauczyciele akademiccy podlegają odpowiedzialności dyscyplinarnej „za postępowanie uchybiające obowiązkom nauczyciela akademickiego lub godności zawodu nauczycielskiego" 22 , a adwokaci i aplikanci adwokaccy „za postępowanie sprzeczne $\mathrm{z}$ prawem, zasadami etyki lub godności zawodu bądź za naruszenie swych obowiązów zawodowych, a adwokaci również za niespełnienie obowiązku zawarcia umowy ubezpieczenia, o którym mowa $w$ art. 8a ust. 1, zgodnie $\mathrm{z}$ przepisami wydanymi na podstawie art. $8 b^{\text {"23 }}$. Jak widać, bez większych problemów można wskazać jako jasną regułę jedynie tę dotyczącą umowy ubezpieczenia od odpowiedzialności cywilnej w przypadku adwokatów. W odniesieniu do kar natomiast mamy do czynienia $z$ enumeratywnym wyliczeniem obejmującym zazwyczaj upomnienie, naganę $\mathrm{i}$ wydalenie $\mathrm{z}$ zawodu oraz dolegliwości czasowe, jak za-; wieszenie uprawnień do wykonywania zawodu, sprawowania funkcji lub grzywnę. W związku z brakiem typizacji przewinień dyscyplinarnych przepisy nie zawierają przyporządkowania między nimi a karami.

Na tych przykładach widać wyraźnie różnice między ustalaniem reguły, którą narusza dany czyn, oraz ustalaniem prawnych konsekwencji tego naruszenia. Pierwsze odbywa się bowiem na podstawie pojẹć niedookreślonych odsyłających do ocen (godność zawodu) lub norm (zasady etyki), drugie natomiast na podstawie swobodnego uznania. Sa to w gruncie rzeczy całkowicie odmienne techniki regulacji ${ }^{24}$, ponieważ te pierwsze ,nie zawierają najczęściej umocowania do dyskrecjonalności, lecz odwohują się do obiektywnych, ogólnych i wiążących wartości [...]. Korelacja między klauzulami generalnymi i dyskrecjonalnością może występować wtedy, gdy kryterium odesłania zawarte w klauzuli jest podstawą rozstrzygnięcia dyskrecjonalnego [...]. Nie jest uprawniony pogląd, że każde rozstrzygnięcie podjęte w warunkach swobody zwiazzanej z pozaprawnym odesłaniem ma charakter uznaniowy

${ }^{22}$ Artykuł 139 ust. 1 ustawy - Prawo o szkolnictwie wyższym z 27 lipca 2005 r., Dz.U. z 2005 r., nr 164, poz. 1365 z późn. zm.

${ }^{23}$ Artykul 80 ustawy - Prawo o adwokaturze z 26 maja 1982 r., Dz.U. z 2002 r., nr 123, poz. $1058 \mathrm{z}$ późn. zm.

${ }^{24} \mathrm{O}$ rozróżnieniu pojęć niedookreślonych i uznania administracyjnego oraz łącznym stosowaniu tych technik por.: $Z$. Niewiadomski [red.], Prawo administracyjne. Cześć ogólna, Warszawa 2002, s. 83-84. 
w odniesieniu do jego treści'”2s. Technikami legislacyjnymi upoważniającymi do swobodnego uznania są zazwyczaj alternatywne zestawienia kilku możliwych rozwiazań lub posługiwanie się zwrotami takimi jak „organ może”, „organ ma prawo" itp. ${ }^{26}$ Ta pierwsza jest używana w przypadku ustawowej regulacji kar dyscyplinarnych, druga natomiast $w$ zakresie materialnych podstaw odpowiedzialności dyscyplinarnej nie występuje.

Należy jednak wskazać na istotne słabości stanowiska, iż pojęcia niedookreślone czy klauzule generalne odsyłają do obiektywnych i ogólnych wartości. Osłabiają one ostrość rozróżnienia między pojęciami niedookreślonymi a swobodnym uznaniem, przynajmniej $w$ zakresie ich stosowania w przypadkach takich regulacji, jak odpowiedzialność dyscyplinarna, tj. gdy wystepuja one obok siebie $i$ istnieje między nimi korelacja, o której pisze cytowany powyżej autor. To z kolei ma znaczenie w ustalaniu dyrektyw orzekania o odpowiedzialności dyscyplinarnej i prowadzi do upodobnienia metodyki stosowania pojęć niedookreślonych i swobodnego uznania w ramach jednej decyzji orzeczniczej. Podstawowym zarzutem wobec tezy o obiektywności i ogólności wartości, do których odsyłają pojęcia niedookreślone, jest jej milczące założenie, które scharakteryzowałbym jako optymistyczny kognitywizm. Trudno poddać je w tym miejscu wyczerpującej krytyce, wystarczy stwierdzić, że jest to założenie na tyle mocne, że bez sformułowania dyrektyw mówiących, w jaki sposób sędzia miałby ustalać treść owych obiektywnych i ogólnych wartości, a następnie w ich świetle oceniać konkretny stan faktyczny, będzie ono w praktyce nieprzydatne. Tymczasem coraz częściej formułuje się pogląd, iż nie tylko w przypadku wykładni pojęć niedooreślonych, ale wykładni prawa w ogóle jej prawidłowość ,nie jest sprawą relacji hipotezy wykładni do rzeczywistości, ale kwestią relacji pomiędzy interpretatorem a jego interlokutorami" ${ }^{27}$, a więc powinna być

${ }^{25}$ B. Wojciechowski, Dyskrecjonalność sędziowska. Studium teoretycznoprawne, Toruń 2004, s. 76-77. W cytowanej pracy jest mowa o klauzulach generalnych, a nie o pojęciach niedookreślonych, co wynika $\mathrm{z}$ charakteru głównego jej przedmiotu, $\mathrm{tj}$. dyskrecjonalności sędziowskiej. Sądzę jednak, że analogie między obydwoma pojęciami i zwiazanymi z nimi technikami legislacyjnymi uzasadniaja odniesienie uwag autora także do pojęć niedookreślonych, przy zastrzeżeniu, że są one stosowane w różnych gałęziach prawa i mimo podobieństw nie są konstrukcjami tożsamymi.

${ }^{26}$ Ibidem, s. 90.

${ }^{27}$ T. Spyra, Granice wykladni prawa. Znaczenie językowe tekstu prawnego jako granica wykladni, Kraków 2006, s. 227. 
ona podporządkowana racjonalności komunikacyjnej. W tym przypadku kryteria racjonalności można o wiele łatwiej przełożyć na dyrektywy praktyczne, skadinąd zbierane w swoiste kodeksy argumentacyjne ${ }^{28}$.

Wykładnia pojęć niedooreślonych stanowiących materialne podstawy odpowiedzialności dyscyplinarnej w sposób dyskursywny budzi jednak zastrzeżenia. Należy bowiem pamiętać o specyficznym charakterze organów dyscyplinarnych, które $\mathrm{z}$ reguły składają się $\mathrm{z}$ osób wykonujących ten sam zawód lub przynajmniej należących do tego samego środowiska, co obwiniony. Zazwyczaj więc postępowanie dyscyplinarne odbywa się w warunkach, w których, przy braku kontroli $z$ zewnątrz, konsens jest stosunkowo łatwo osiagalny, a przecież odpowiedzialność dyscyplinama pełni funkcje nie tylko wewnątrzgrupowe, ale także ogólnospołeczne (integralność zawodu i integralność zawodowa). Dlatego też odrzucając stanowisko obiektywistyczne przy ustalaniu reguł, których naruszenie powoduje odpowiedzialność dyscyplinarną, nie należy popadać ponownie w myślenie w kategoriach, tym razem rozumianej grupowo wstrzemięźliwości, a więc stawać na stanowisku subiektywistycznym. Organy dyscyplinarne powinny, obok własnego doświadczenia zawodowego i znajomości środowiska, jak najszerzej uwzględniać różne, pozaśrodowiskowe punkty widzenia, w szczególności postawę ewentualnego pokrzywdzonego i poziom zaufania społecznego, a najlepiej w rzeczywistości ich wysłuchiwać. To wymagałoby jednak znacznych reform postępowań dyscyplinarnych i zniesienia wielu ograniczeń udziału w nich przedstawicieli opinii publicznej, przede wszystkim najdalej idącej swego rodzaju ,półtajności” niektórych z nich. Innymi słowy, wykładnia pojęć niedookreślonych materialnego prawa dyscyplinarnego, zarówno w znaczeniu pragmatycznym, jak i apragmatycznym, powinna mieć na celu ustalenie takich reguł postępowania osób podlegających odpowiedzialności, które jak najszerzej byłyby akceptowane przez zainteresowane strony i w ten sposób służyły ich integracji wokół wartości, do których dana klauzula odsyła.

Pozostaje jednak w mocy konkluzja, iż mimo pewnych podobieństw i praktycznych związków regulacji za pomocą pojęć niedookreślonych,

${ }^{28} \mathrm{R}$. Alexy, Theorie der juristischen Argumentation. Die Theorie des rationalen Diskurses als Theorie der juristischen Begrïndung, Frankfurt am Main 1992; J. Stelmach, Kodeks argumentacyjny dla prawników, Kraków 2003. 
a więc ustawowej nieokreśloności reguł, których naruszenie powoduje odpowiedzialność dyscyplinarna, oraz swobodnego uznania w zakresie wymierzania kar dyscyplinarnych, pozostają one czymś rodzajowo innym. To powoduje konieczność odpowiedzenia na pytanie o charakter owego uznania, tj. rozwiązanie drugiego $z$ postawionych wcześniej problemów, a więc oceny, czy swobodne uznanie w zakresie odpowiedzialności dyscyplinarnej ma charakter raczej administracyjny czy też sędziowski. Wydaje się, iż już na wstępie można odrzucić stanowiska skrajne, ponieważ organy dyscyplinarne nie sq̨ ani wymiarem sprawiedliwości, ani administracją publiczną. Pierwsze jest wykluczone na mocy regulacji konstytucyjnych, drugie natomiast wątpliwe ze względu na prawne, w szczególności proceduralne, formy ich działania. Prowadzą one bowiem postępowanie modelowo zbliżone do karnego, stosując zresztą subsydiarnie przepisy kodeksu postępowania karnego, kończąc je orzeczeniem. Należy zatem domniemywać, iż tak jak organy dyscypliname mają swoisty charakter, tak też zakres swobodnego uznania i jego granice będą nietypowe.

Istnieją dwie najważniejsze $\mathrm{z}$ punktu widzenia odpowiedzialności dyscyplinarnej różnice między uznaniem administracyjnym a dyskrecjonalnością sędziowską ${ }^{29}$. Po pierwsze, swoboda administracji publicznej przy podejmowaniu decyzji ma charakter celowościowy, tj. umożliwia organom administracyjnym ocene, jakie działanie będzie w danej sytuacji najbardziej skuteczne i opłacalne, także z punktu widzenia założeń o charakterze strategicznym. Jest nawet dopuszczalny pewien zakres politycznego oportunizmu. Dyskrecjonalność sędziowska natomiast ma charakter słusznościowy, a więc ma jedynie umożliwić wydawanie sprawiedliwych orzeczeń przez uelastycznienie sztywnych reguł wyrokowania i dopasowanie konsekwencji prawnych do różnorodnych konkretnych stanów faktycznych. Po drugie, $\mathrm{z}$ tego zróżnicowanego charakteru swobodnego uznania $\mathrm{w}$ administracji publicznej i wymiarze sprawiedliwości, można wyprowadzić zasady korzystania $z$ owej swobody. W obu przypadkach dotyczą one bezpośrednio zagadnienia znanego jako one right answer, czyli założenia, że ustalanie i uzasadnianie każdej decyzji orzeczniczej powinno być podporządkowane znalezieniu jedynego słusznego rozwiązania danego problemu prawnego, co oczywiście zakłada, że takie jedyne rozwiązanie da się, choć czasem za pomocą skomplikowanych metod, z każdego systemu prawnego

${ }^{29}$ B. Wojciechowski, Dyskrecjonalność sędziowska..., s. 102-103. 
wyprowadzić. Tak więc swoboda sędziego jest tak naprawdę jedynie swobodą poszukiwań właściwego rozwiązania, a nie swobodą decydowania i uzasadniania. Nie dotyczy to jednak sfery administrowania, w której istnieje potrzeba uwzględniania wielu pozaprawnych, w tym także strategicznych, czynników.

$\mathrm{Z}$ punktu widzenia funkcji integracyjnej odpowiedzialności dyscyplinarnej bardziej właściwe wydaje się przyjęcie, że swobodne uznanie w jej przypadku ma charakter administracyjny. Jeśli bowiem założyć, że organy dyscyplinarne powinny poszukiwać jedynego słusznego rozwiązania w zakresie kary, przy czym nie mają prawa kształtować własnej strategii osiągania za pomoca orzecznictwa określonych celów, to brakowałoby podstaw do uwzględniania wielu istotnych czynników przy wydawaniu konkretnych orzeczen, takich jak potrzeba przeciwdziałania najczęściej występującym patologiom, oczekiwania społeczne wobec danej grupy oraz różnorodņy i zmienny w czasie poziom zaufania, jakim jest ona darzona czy wreszcie osobista postawa obwinionego, stopień jego winy i ocena, czy daje on nadal rękojmię właściwego wykonywania zawodu czy sprawowania funkcji. Takich podstaw nie może dostarczyć analogiczne stosowanie karnistycznych dyrektyw wymiaru kary, ponieważ z jednej strony nie uwzględniają one wszystkich czynników, które obejmuje funkcja integracyjna odpowiedzialności dyscyplinarnej, a przynajmniej inaczej rozłożone są w ich zakresie akcenty, a z drugiej strony trudno znaleźć uzasadnienie dla analogicznego stosowania akurat tylko tych zasad prawa karnego, a nie na przykład samego zakazu analogii. Innymi słowy, prawo dyscyplinarne nie jest takim prawem karnym, które różni się od właściwego prawa karnego tylko tym, że jest prawie całkowicie niedookreślone, tak bowiem ujęte, naruszałoby bez mała wszystkie standardy współczesnego państwa konstytucyjnego. W związku z tym prawo dyscypliname w ogóle nie jest prawem kamym.

Trzecim problemem, którym należy się zająć, jest zagadnienie konkretnych dyrektyw orzekania w zakresie odpowiedzialności dyscyplinarnej określonych grup. Jeśli bowiem udało się dokonać pewnych uogólnień dotyczących jej funkcji oraz prawnych regulacji, to mają one jednak charakter formalny. Nadal otwarta pozostaje kwestia, w jaki sposób te formalne ustalenia stosować do wartości czy nawet praktyki społecznej w zakresie różnorodnych przecież grup podporządkowanych prawu dyscyplinarnemu. Punktem wyjścia przy rozpatrywaniu konkretnej sprawy 
dyscyplinarnej jest zazwyczaj poczucie lub intuicja, że naruszone zostały pewne reguły, na przykład „zasady etyki zawodowej lub godności zawodu". To poczucie lub intuicja jest często nieokreślona i zadaniem organu dyscyplinarnego jest jego racjonalna ocena $\mathrm{z}$ punktu widzenia funkcji odpowiedzialności dyscyplinarnej.

Na pierwszym etapie tej oceny należy odpowiedzieć na pytanie, czy została naruszona konkretna reguła postępowania, ponieważ samo powołanie się na klauzule generalne jest przy wymierzaniu kar daleko niewystarczające. Jeśli takie reguły są skodyfikowane w postaci odpowiedniego kodeksu etycznego, organ dyscyplinarny ma ułatwione zadanie, w żadnym wypadku nie powinno to jednak kończyć jego czynności, ponieważ zarówno gdy dany czyn narusza regułę kodeksu, jak i gdy stosownej reguły w nim odnaleźć nie można, należy pamiętać, że podstawą prawną orzeczenia jest przepis prawa zawierający klauzulę generalną i owe reguły muszą być uzasadnione wartościami, do których te klauzule odsyłaja, a nie wyłącznie formalnym odwołaniem do tego, czy coś się w kodeksie znajduje czy też nie. Kodeks etyczny jest tylko miękkim prawem i nie może być samodzielną podstawą orzeczeń organów dyscyplinarnych, a więc zawarte $w$ nim reguły należy poddać takiej samej ocenie, jak w przypadku tych pozakodeksowych.

Ocena danej reguły powinna uwzględniać następujące czynniki wynikające $\mathrm{z}$ funkcji integracyjnej odpowiedzialności dyscyplinarnej, w szczególności wymogów dotyczących integralności zawodowej i integralności zawodu. Po pierwsze, należy przyjąć takie jej brzmienie, które w jak najszerszym zakresie pokrywałoby się z powszechnymi standardami postepowania i jednocześnie wystarczało do realizacji wartości, które ustawodawca uznał za nieodzowne w danej grupie podlegającej odpowiedzialności dyscyplinarnej. Innymi słowy, reguła ta powinna wymagać szczególnych standardów tylko w uzasadnionych przypadkach, a zatem jak najszerzej gwarantować jednolitość postępowania, a więc i zakres wolności, członków grupy i reszty spoleczeństwa. Po drugie, powinna być ona adresowana do wszystkich członków grupy, aby gwarantować jednolitość postępowania w ramach grupy i nie tworzyć niepotrzebnych dodatkowych nierówności. Po trzecie, musi uwzględniać oczekiwania społeczne wobec grupy, które składają się na odgrywaną przez tę grupę rolę zawodową czy, szerzej, społeczną, a więc także na społeczny punkt widzenia wartości, które mają poszukiwaną regułę uzasadniać. Po czwarte, należy brać pod uwagę poziom zaufania lub nieufności, którym się ta grupa w społeczeństwie cieszy, w ten 
sposób, że im gorszą ma reputację, tym wyższych, bardziej szczególnych standardów powinna przestrzegać. Spełnienie tych wymogów przez ustalaną regułę oznacza, iż postępowanie zgodnie $z$ nią pozwoli w sposób proporcjonalny zapewnić spójność ocen zarówno wewnątrzgrupowych, jak i społecznych w zakresie realizacji omawianych wartości, a więc w gruncie rzeczy umożliwi integrację wokół nich.

Jeśli organ dyscyplinarny jest w stanie wykazać, że została naruszona reguła, którą przy spełnieniu powyższych warunków uzasadniają wartości, do których odsyłaja przepisy ustanawiające materialne standardy odpowiedzialności dyscyplinarnej, to powinien następnie odpowiedzieć na pytanie, jaką karę należy sprawcy owego czynu wymierzyć. Swobodne uznanie w tym zakresie oznacza, iż brakuje jakiegokolwiek przyporządkowania między typami czynów a rodzajami kar, których zamknięty katalog przewiduje ustawa. Trudno znaleźć uzasadnienie dla jakichkolwiek sztywnych reguł wymiaru kary, które mogłyby zostać wykształcone w praktyce, ponieważ byłyby one sprzeczne $\mathrm{z}$ celem, dla którego organom dyscyplinarnym ustawodawca ową swobodę pozostawił. Wydaje się bowiem, że przyjęto terí dość powszechnie stosowany model odpowiedzialności dyscyplinarnej po to, aby organy dyscyplinarne w każdej konkretnej sytuacji mogły wziąć pod uwagę wszelkie okoliczności dotyczące zarówno samego czynu i jego sprawcy, jak i ich społecznego kontekstu. Dzięki temu można rozsądnie wyobrazić sobie sytuację, że taka sama kara jest wymierzana za ciężkie naruszenie reguł postępowania w danej grupie, które wywołuje powszechne oburzenie, jednak przy niewielkim stopniu zawinienia polegającym na nieumyślności oraz za czyn będący stosunkowo lekkim przewinieniem, lecz przy szczególnym nasileniu złej woli ze strony sprawcy. Sądzę nawet, że można znaleźć takie przewinienia dyscyplinarne, w których kara mogłaby być wymierzona w ogóle bez uwzględniania strony podmiotowej, na zasadzie swoiście rozumianego ryzyka zawodowego ${ }^{30}$. Jeśli bowiem ich nieukaranie doprowadziłoby do całkowitego podważenia zaufania do sprawcy lub całej grupy podlegającej odpowiedzialności dyscyplinarnej, jej funkcja integracyjna nie zostałaby wypełniona, a to przekreślałoby w zasadzie sens istnienia tej instytucji. Mówimy tu jednak o przypadkach ekstremalnych. W normalnych warunkach, charakteryzujących się w miarę harmonijnymi relacjami

${ }^{30}$ P. Skuczyński, Nadużycie prawa przez prawnika a etyka zawodowa, [w:] H. Izdebski, A. Stępkowski [red.], Nadużycie prawa, Warszawa 2003. 
między członkami danej grupy oraz grupą a społeczeństwem, powinno się brać pod uwage wszystkie trzy aspekty integralności w realizacji wartości grupowych przy użyciu instytucji odpowiedzialności dyscyplinamej.

Tak więc wymiar kary dyscyplinarnej za konkretny czyn powinien brać pod uwage przede wszystkim trzy kryteria. Po pierwsze, na ile czyn ten podważa zaufanie do całej grupy w oczach opinii społecznej i jaki jest niezbędny stopień dolegliwości, aby ewentualne straty w tym zakresie odrobić. Należy przy tym zauważyć, iż aby jeden czyn nadszarpnął zaufanie do całej grupy zawodowej musi być on bardzo poważny i najczęściej dotyczy takich przewinień dyscyplinarnych, które mają jednocześnie charakter kryminalny. Po drugie, istotne jest wewnątrzgrupowe stanowisko wobec danego standardu, który został naruszony. Jeśli bowiem dana reguła postępowania jest naruszana często i taktowana $\mathrm{z}$ pobłażaniem, może doprowadzić do trwałego rozminięcia się oczekiwań społecznych wobec grupy $i$ jej wizerunku wobec samej siebie. Organy dyscyplinarne powinny więc swym orzecznictwem wyraźnie dawać do zrozumienia, jakie reguły w danej grupie obowiązuja uciekając się nawet czasem do prowadzenia kampanii przeciwko najpowszechniejszym naruszeniom wartości, do których ochrony sa powołane. Po trzecie wreszcie, należy szeroko uwzględniać integralność moralną samego obwinionego i jego stosunek do owych wartości. Istotne z tego punktu widzenia będą więc motywy i pobudki jego działania, ewentualna wielokrotność i uporczywość w naruszaniu reguł oraz rękojmia należytego postępowania w przyszłości. To, że czynniki te znajdują się na końcu, nie oznacza oczywiście, że mają one mniejsze znaczenie niż pozostałe.

Omówione dotychczas zagadnienia dotyczą przede wszystkim materialnoprawnych podstaw odpowiedzialności dyscyplinarnej. Poczynione ustalenia nie pozostają jednak bez wpływu na wiele zagadnień formalnego prawa dyscyplinarnego, a więc dotyczącego ustroju organów dyscyplinarnych, postępowania przed nimi oraz nadzoru judykacyjnego nad odpowiedzialnością dyscyplinarną. Należy zwrócić na nie, chociażby pobieżnie, uwagę, tym bardziej, że cieszą się one szczególnym zainteresowaniem doktryny i orzecznictwa.

W zakresie ustroju organów dyscyplinarnych zwraca uwage przede wszystkim kwestia, kto powinien w nich zasiadać i w jakiej relacji do podlegajacych odpowiedzialności dyscyplinarnej członków grupy powinny pozostawać te osoby. Jak wspomniałem wcześniej, z jednej strony może to 
być swoisty sąd równych, w którym zasiadają kadencyjnie powoływani przedstawiciele danej grupy, z drugiej spotyka się rozwiązania, że odpowiedzialność dyscyplinarną wymierzają służbowi przełożeni. W obu przypadkach są to jednak osoby wykonujące ten sam zawód, o podobnym przygotowaniu i doświadczeniu, a więc $z$ założenia równie kompetentne, jeśli chodzi o ocenȩ, co w danym zawodzie jest postępowaniem właściwym. Jest to w pełni uzasadnione także ze względu na integracyjną funkcję odpowiedzialności dyscyplinarnej, ponieważ może zapewnić rzeczywistą samoregulacje w ramach danych grup i w ten sposób budować relacje wspólnotowe wewnątrz nich oraz budować zaufanie w relacjach ze społeczeństwem.

Należy jednak zwrócić uwagę, że występują także organy dyscyplinarne o składzie mieszanym (na przykład w szkołach wyższych komisje dyscyplinarne ds. studenckich sa obsadzane przez nauczycieli akademickich i studentów) oraz że proponuje się wprowadzanie jednolitego sądownictwa dyscyplinarnego dla wielu grup zawodowych (na przykład w odniesieniu do zawodów prawniczych przez sądy powszechne ${ }^{31}$, a więc organy obsadzone przez sędziów zawodowych). Sądzę, że takie zaprojektowanie órganów dyscyplinarnych może także znajdować swoje uzasadnienie w funkcji integracyjnej w przypadkach, w których dezintegracja i rozczłonkowanie pewnych środowisk, mimo że uzasadnione przez różnice w odgrywanych rolach zawodowych czy społecznych, ma jednak negatywne konsekwencje w postaci braku korespondencji między oczekiwaniami wobec nich jako całości a różnymi na nie reakcjami, w poszczególnych, formalnie autonomicznych podgrupach. Należy jednak pamiętać, że tworzenie wspólnych organów dyscyplinarnych powinno prowadzić do integracji różnych grup, a nie podporządkowywania jednych drugim. Dlatego na przykład projekt odnoszący się do wspólnej odpowiedzialności dyscyplinarnej zawodów prawniczych powinien zostać uzupełniony o uwzględnienie owej różnorodności w ramach zawodu, która jest faktem i której nie można ignorować. Ciekawe $z$ tego punktu widzenia są rozwiązania niemieckie, gdzie zrównoważono tradycyjne, silniejsze zresztą niż w wielu innych krajach, związki wolnych zawodów prawniczych z sądami, których nadzorowi historycznie podlegały, poprzez zorganizowanie pierwszej instancji sądownictwa dyscyplinarnego w ramach poszczególnych samorządów zawodowych, drugą instancję umieszczając natomiast w ramach sądownictwa powszechnego,

${ }^{31}$ Projekt Ministerstwa Sprawiedliwości, druk sejmowy nr 970. 
lecz z udziałem w orzekających składach ławników rekrutujących się z tego samego, co obwiniony, zawodu.

Inną kwestią wskazywaną jako wymagającą reform w zakresie formalnego prawa dyscyplinarnego jest różnorodność przepisów proceduralnych. Są one zazwyczaj tylko ramowo uregulowane w poszczególnych ustawach, w szczegółach odsyłając bądź do wydawanych na ich podstawach rozporządzeń, bądź do kodeksu postępowania karnego. $Z$ tego powodu występuje wiele nieuzasadnionych różnic dotyczących między innymi uprawnień organów dyscyplinarnych w zakresie gromadzenia dowodów, możliwości wydawania im poleceń przez inne organy danej instytucji czy też w sytuacji obwinionego i jego prawa do obrony. Największe jednak rozbieżności występuja, jeśli chodzi o nadzór sądowy nad wymierzaniem odpowiedzialności dyscyplinarnej. Nie podlega dyskusji, że ustawodawca w każdym przypadku powinien zagwarantować prawo do sądu ${ }^{32}$. Nie jest natomiast jasne, które $\mathrm{z}$ różnych występujących obecnie rozwiązań jest najwłaściwsze: odwołania od orzeczeń sądów dyscyplinarnych do sądów powszechnych, administracyjnych czy też kasacja do Sąu Najwyższego ${ }^{33}$.

Nie sądze, aby pomyst jednego lub tylko jednolitego uregulowania postępowań dyscyplinarnych był wart realizacji. Tak samo bowiem, jak w przypadku prawa materialnego $\mathrm{i}$ ustrojowego, w regulacjach proceduralnych znajdują odzwierciedlenie różnice między grupami, które odpowiedzialności dyscyplinarnej podlegaja. Regulacje te powinny uwzględniać takie czynniki, jak stopień niezależności pewnych grup, w szczególności tych, którym przysługuja immunitety formalne, zainteresowanie osób, na rzecz których są świadczone usługi, czyli klientów lub pacjentów, oraz potrzeba ochrony tajemnicy zawodowej. Niewątpliwie jednak można podejmować próby wypracowania wspólnych zasad dla wszystkich takich postępowań.

Na pewno jedną $z$ nich jest właśnie prawo do sądu, a więc możliwość odwołania się od orzeczenia dyscyplinarnego do sądu. Prawo to jednak nie powinno być rozumiane zbyt szeroko $\mathrm{z}$ dwóch względów. Po pierwsze, sprawy dyscyplinarne nie są sprawami z zakresu wymiaru sprawiedliwości tylko przekazanymi organom pozasądowym do wstępnego rozpatrzenia ${ }^{34}$,

${ }^{32}$ Wyroki TK z 16 listopada 1999 r., SK 11/99 (OTK ZU 1999/7/158) oraz z 8 grudnia 1998 r., K $41 / 97$ (OTK ZU 1998/7/117) oraz wyrok SN z 7 kwietnia 1999 r., I PKN 648/98 (OSNP 2000/11/423).

${ }^{33}$ A. Wasilewski, Prawo do sqdu..., s. 41-43.

${ }^{34}$ Wyrok TK z 8 grudnia 1998 r., K 41/97 (OTK ZU 1998/7/117). 
tak jak nie są nimi zresztą wszelkie sprawy administracyjne. Założenie przeciwne oznaczałoby uznanie, że orzekać w nich powinny w normalnym trybie sądy, a organy dyscyplinarne mogłyby funkcjonować jedynie na zasadzie wyjątku. Po drugie, dyskursywne i integrujące dane środowiska ustalanie reguł, których naruszenie pociąga odpowiedzialność dyscyplinarna, oraz swobodne uznanie w wymierzaniu kar za to naruszenie nie moga być $z$ wielu względów realizowane przez sądy. Nie tylko więc nie należy powierzać im rozstrzygania w tym zakresie, ale także nadzór nad działalnością organów dyscyplinarnych powinien ograniczać się do formalnej kontroli tego, czy przestrzegają one zasad orzekania, w tym czy właściwie prowadzą postępowania, biorą pod uwagę wszelkie okoliczności sprawy i w sposób wystarczający uzasadniają swoje decyzje. Dlatego też sądy powinny mieć $w$ stosunku do orzeczeń dyscyplinarnych uprawnienia jedynie kasatoryjne, a nie reformatoryjne. To natomiast, czy nadzór ten powinjien mieć formę skargi do Naczelnego Sądu Administracyjnego czy kasacji do Sądu Najwyższego jest sprawą wtórną z punktu widzenia samej odpowiedziạlności dyscyplinarnej. Decydujące znaczenie mają tu raczej regulacje konstytucyjne, przede wszystkim dotyczące dwuinstancyjności postępowania.

Punktem wyjścia niniejszych rozważań było rozróżnienie odpowiedzialności dyscyplinarnej sensu largo i sensu proprio. Z jednej strony powyższe rozważania moga prowadzić do wniosku, że przyjęta terminologia nie jest poprawna, ponieważ zarówno tradycje oraz regulacje, jak i funkcje obu typów wskazują raczej na to, że poza nazwą, używaną zresztą tylko w języku prawniczym, nie mają one ze sobą wiele wspólnego. Odpowiedzialność dyscyplinarna wolnych zawodów czy shuzb publicznych nie jest podtypem pracowniczej odpowiedzialności dyscyplinarnej w szerokim znaczeniu. Z drugiej jednak strony wiele przemawia za podtrzymaniem tego rozróżnienia, jak chociażby fakt, że ostre przeciwstawianie wykonywania zawodów w formach pracy najemnej, wolnych zawodów i słyżby publicznej nie jest do końca uzasadnione. Elementy rynku i regulacji mieszają się bowiem we wszystkich tych formach, co prowadzi do swego rodzaju nowego myślenia korporacyjnego. Jego podstawą nie są jednak korporacyjne przywileje, które dziś stawiają tradycyjny korporacjonizm pod pręgierzem krytyki politycznej, lecz profesjonalizm i społeczna odpowiedzialność, które w przypadku globalnego funkcjonowania przedsiębiorstw czy nawet całych zawodów jest oczywiste. Dlatego można chyba przewidywać swoistą konwergencję obu typów 
odpowiedzialności dyscyplinarnej, której początkiem jest wypełnianie podobnych funkcji, daleko wykraczających poza obszar innych mechanizmów odpowiedzialności prawnej.

Odpowiedzialność dyscyplinarna jest instytucją w dużym stopniu normatywnie otwarta, $w$ tym sensie, że ciągłym zmianom podlegają nie tylko przepisy ustaw i rozporządzeń, które jej dotycza, ale także pisane i niepisane reguty będące jej podstawa, dyrektywy orzekania, w tym przede wszystkim wymiaru kary, ale także jej najważniejsze funkcje, a więc cele i zadania, które ma ona wypełniać. Wydaje się dziś, iż sens istnienia odpowiedzialności dyscyplinarnej zawiera się przede wszystkim, w tym, że może integrować ona rożne grupy społeczne wokół pewnych, mających zazwyczaj zawodowy, ale też publiczny charakter. Dzięki swojej elastyczności i niedookreśloności pozwala ona regulować te obszary życia społecznego, które wymykają się tradycyjnym formom odpowiedzialności prawnej: karnej i cywilnej, a co ważne, jako instytucja prawna pozwala robić to przy zachowaniu niezbędnych gwarancji praw jednostki w państwie konstytucyjnym. Aby mogła to zadanie wypełniać skutecznie, konieczna jest jednak świadomość, że swoboda pozostawiona organom dyscyplinarnym musi być wykorzystywana w sposób celowy i konsekwentny. Świadomość tę, niezbędną zarówno wśród osób należących do środowisk podlegających odpowiedzialności dyscyplinarnej, jak i w ich społecznym otoczeniu należy kształtować nie tylko przez rozsądne i kierujące się stosownymi dyrektywami orzecznictwo, ale także przez otwarcie organów dyscyplinarnych na krytyczną debatę publiczną na temat ich poczynań, edukację dotyczącą ich pracy, publikowanie orzeczeń, a także teoretyczną autorefleksję. 